\title{
Die Barmhartigheidsbediening van die NG Kerk van Natal: - afhanklik en eksklusief?
}

\author{
R B van Aarde' \\ (Universiteit van Pretoria)
}

\section{ABSTRACT}

The ministry of compassion of the Dutch Reformed Church in Natal dependent and exclusive?

This study highlights two major concerns in the history of the Dutch Reformed Church of Natal's ministry of compassion. The church's work became financially too dependent on government subsidies. The work originally started off with church finances, but was later financed by government. In principle there is nothing wrong with such a partnership, but the present financial dependency will have to make room for an independent ministry of compassion. The church's ministry of compassion was also mainly focussed on the Afrikaner nation. In this the church supported the apartheid system of the day and started the perception that services of compassion are for the White community while missionary work is focussed on the Black communities. What history teaches us in this field of compassion and caring can help to rectify the ministry of compassign of the Dutch Reformed Church in Kwa Zulu/Natal and help the church to avoid the same mistakes in future

\section{INLEIDING}

Twee groot vraagstukke wat tot met die eerste demokratiese verkiesing in 1994 soos ' $n$ goue draad deur die barmhartigheidsgeskiedenis van die NG Kerk loop is die noue samewerking met die staat en die aandrang dat barmhartigheidsarmsorgdienste in die eerste plek aan die Afrikanervolk gelewer sal word. In die barmhartigheidsgeskiedenis van die NG Kerk in wyer verband was hierdie twee aspekte deurlopend aan die orde.

Dit het die skrywer laat vra na die rol wat die bogenoemde vraagstukke in die barmhartigheidsgeskiedenis van die NG Kerk in Natal gespeel het. Hipoteties word die volgende stellings gemaak, wat in die artikel verder ondersoek sal word:

\footnotetext{
${ }^{1}$ Hierdie artikel is gebaseer op 'n proefskrif. in 1999 ingedien by die Departement Kerkgeskiedenis, Universiteit van Pretoria, met die titel: "Die Barmhartigheidsbediening van die Ned Geref Kerk van Natal: 'n Kerkhistoriese Perspektief".
} 


\section{$1.1 \quad$ Hipotese 1}

Die kerk het ten opsigte van sy diens van barmhartigheid te afhanklik van die staat geraak en hierdie diens so uitgebou dat dit onmoontlik geword het om sonder staatsubsidies klaar te kom. Die gevolg is dat die kerk tans ' $n$ groot mate van onsekerheid belcef vir die toekoms van sy maatskaplike dienste.

\subsection{Hipotese 2}

Die kerk se besondere barmhartigheidsbetrokkenheid by die Afrikanervolk het sy spontane betrokkenheid by ander volke en kultuurgroepe negeer. Hierdie vroeëre uitsluiting van ander volke uit die kerk se barmhartigheidsbediening het die kerk se bona fides in gedrang gebring.

\section{DIENS VAN BARMHARTIGHEID AAN DIE AFRIKANER- VOLK}

\subsection{Die Kerk in afsondering en na binne gerig}

Individuele persone in nood uit ander volke is dikwels nog ingetrek en gehelp, maar min of geen uitreiking na gemeenskappe buite die Afrikanervolk is gedoen nie. Trouens, die NG Kerk van Natal het deur die loop van die geskiedenis, homself al meer geïsoleer. Tot so laat as die sewentigerjare van hierdie eeu, het die Natalse Sinode, saam met die ander sinodes, homself grootliks onttrek van ekumeniese werksaamhede en homself al meer afgesonder.

' $n$ Wêreld Sondagskoolkonferensie is in 1940 in Durban gehou. Die NG Kerk van Natal het egter nie sy weg oopgesien om daaraan deel te neem nie, en neem die volgende besluit oor die saak:

"Aangesien die Wêreld Sondagskool Konferensie wat in 1940 in Durban gehou sal word, ' $n$ geleentheid vir konferensie met Christene uit ander dele van die wêreld is, was die NG Kerk van Natal begerig om aan die Konferensie deel te neem, mits die beginsel van rasse-apartheid deurgaans toegepas word.

Tot ons leed is hierdie voorwaarde nie toegestaan nie en om hierdie rede, asook omdat die kwessie van rasseverhouding tussen blankes en gekleurdes vir die teenwoordige baie delikaat is in ons land, en omdat ons oortuig is dat sodanige opheffing van die kleurlyn die rasseverhouding in Suid Afrika in die toekoms skadelik sal beïnvloed, besluit die Sinode om nie aan genoemde Konferensie deel te neem nie" (Notule van die Sinode van Natal 1939).

Hierdie besluit moet negatief beoordeel word, aangesien dit die politicke rasseskeiding, reeds voor die bewindsoorname van die Nasionale Party, in dic kerklik-godsdienstige arena plaas. Die feit dat die besluit lank voor die bewindsoorname van die Nasionale Party geneem is, plaas die 
kerk in ' $n$ sekere sin aan die voorpunt van die apartheidsfilosofie. Die NG Kerk is ook al dikwels daarvan beskuldig dat hy die politici en die apartheidspolitiek van die dag nagevolg en teologies probeer regverdig het. Hier moet egter bely word dat die kerk van tyd tot tyd eerder die voorloper in die saak van rasseskeiding was waarop die politieke denke en praktyk dan gevolg het. Positief kan dieselfde waarneming ook weer in die tagtigerjare ten opsigte van die beëindiging van apartheid en die skepping van ' $n$ nuwe demokrasie gemaak word. Hierin het die kerk ook oor ' $n$ aantal jare ' $n$ invloed na die politieke denke laat uitgaan wat uiteindelik tot die afbreek van apartheid gelei het.

Op dieselfde sinodesitting van 1939 word dit tydens ' $n$ bespreking "betreur" dat die Provinsiale owerheid die Kerk se aanspraak om namens die Afrikaner in Natal te praat, bevraagteken. Die spreker voel dat die Kerk dan tog wel namens die "denkende deel van die Afrikaner kan praat" Notule van die Sinode van Natal 1939).

Uit die geskiedenis is dit duidelik dat die Natalse Kerk sy barmhartigheidstaak wyer gesien het as slegs sy eie lidmate, maar dit blyk dat die diens van barmhartigheid nie wyer as die Afrikanervolk gegaan het nie. Op die uiterste is nog gepraat van die "armblankevraagstuk", maar die nood van duisende Swartmense en Indiërs (ander volke) is, verkcerdelik, as die diensveld van die sending gesien. Van der Watt (1987:288) sê tereg dat die barmhartigheidsterrein van die begin af wyer gesien is en ' $n$ program van aksie ook op die groter publiek gerig is. Maar dan gaan hy voort deur te verwys na die verskillende volkskongresse, armoede vraagstuk en verstedelikingsprobleem van die Afrikaner. Dit bevestig die standpunt dat diens van barmhartigheid uitsluitlik op die Afrikanervolk gerig was.

Daar is ook deurgaans besluite geneem wat die bogenoemde standpunt bevestig. Die Sinode neem in 1937 kennis dat die geestelike bearbeiding van die "minder gegoede mede-Afrikaners" in Mt Prospect en Ingogo na die aanstelling van ds Van der Merwe nou goed verloop (Notule van die Sinode van Natal 1937).

In 1951 rapporteer die Sinodale Armesorgkommissie aan die Sinode van Natal dat hy as welsynsorganisasie by die Departement van Volkswelsyn geregistreer het. In die Konstitusie wat aan die Sinode voorgelê is, word die oogmerk van die Armesorgkommissie soos volg beskryf: "Die oogmerk van die vereniging is om die sorgbehoewende deel van ons volksgenote stoflik, sedelik en geestelik tot diens te wees." (Agenda van die Sinode van Natal 1951:56).

Hiermee word amptelik bevestig wat teen daardie tyd alreeds praktyk was, naamlik. dat barmhartigheidsdiens hoofsaaklik of selfs uitsluitlik op die volksgenote gerig was.

Aan die ander kant was die Kerk van Natal ook weer nie ongevoelig teenoor die nood en behoeftes van ander bevolkingsgroepe nie. In sy verslag aan die Sinode van 1961 stel die Sinodale Armesorgkommissie die 
volgende: "Tot dusver is daar van Afrikaanse kant en van die kant van ons Kerk nog weinig gedoen aan gesinsorgdienste aan die nie-blanke groepe in ons land. U Kommissie is van mening dat, in medewerking met die Sinodale Sendingkommissie, ' $n$ begin gemaak word met die stigting van ' $n$ welsynskomitee vir die kleurlinggemeenskap in Durban en ' $n$ opgeleide maatskaplike werkster in diens geneem word. Desnoods kan u Kommissie ook finansieel bydra tot hierdie werk" (Agenda van die Sinode van Natal 1961:328).

Hierdie welsynskomitee sou vir die eerste paar jaar as 'n onderkomitee van die Armesorgraad van Durban funksioneer.

In 1975 rapporteer die SKDB soos volg aan die Sinode: "In lyn met u kommissie se doelstelling om die hulpbehoewende deel van ons volksgenote en veral die van die NG Kerk tot diens te wees, dien gemeld te word dat $67 \%$ van die kliënte lidmate van ons kerk en die twee ander susterskerke is. $21 \%$ behoort aan sektekerke en voorts word daar ook aan Engelstaliges aandag gegee en laasgenoemde verteenwoordig omtrent $12 \%$ van die totale gevallelading" (Agenda van die Sinode van Natal 1975:164).

Hier kom nou ' $n$ duidelike verskuiwing na ander persone in nood buite die NG Kerk, alhoewel die doelstelling van die SKDB nog dieselfde bly. Die feit dat hier vir die eerste keer ook na Engelssprekendes verwys word, kan as ' $n$ voorloper van die Kerk se toekomstige denkverskuiwing hieroor beskou word.

Ten spyte van die positiewe klanke in 1975 bly dit die Kerk se standpunt dat maatskaplike dienste ten behoewe van "blanke geloofs- en volksgenote, en in besonder aan lidmate van die NG Kerk" gelewer word. In 1983 waarsku die SKDB in sy verslag dat die Christelike Maatskaplike Rade se gevallelading nie sodanig mag vergroot dat daar nie meer sinvol aan noodlydende lidmate van die Kerk self aandag gegee kan word nie. Op daardie stadium was daar uit ' $n$ totaal van 1315 gevalle, 760 lidmate van die NG Kerk en 101 van die twee Afrikaanse susterskerke (Agenda van die Sinode van Natal 1983:177).

Die bogenoemde waarskuwing teen ' $n$ oorstroming van buite-kerklikes en lidmate van ander kerke het dus in 1983 die kring van dienslewering ook weer kleiner getrek as die Blanke ras (Agenda van die Sinode van Natal 1983:178). Hier het dit duidelik daaroor gegaan dat ander kerke veronderstel is om vir eie (Blanke) lidmate te sorg en dat dit nie ook die verantwoordelikheid van die NG Kerk behoort te wees nie. Tog is dit duidelik dat die verskuiwing wat in 1975 begin het, al meer momentum gekry het.

Die ware denkverskuiwing ten opsigte van diens aan nie-lidmate het teen die middel van die tagtiger jare plaasgevind. Die volkskerkgedagte van vroeër het in 1986 met die aanvaarding van die getuienisdokument, Kerk en Samelewing, plek gemaak vir die suiwerder kerkbegrip dat lidmaatskap oor 
alle taal-, kultuur- en rassegrense heen strek. "Die lidmaatskap van die NG Kerk is oop" (Kerk en Samelewing 1986:46).

Hierna het die dienslewering van die NG Kerk: Maatskaplike Dienste) in Natal ook totaal oopgegaan en word nou dienste aan alle mense in nood gelewer, ongeag taal, kultuur of geloof. Die lidmate van die Kerk word natuurlik steeds as die barmhartigheidsdiens se eerste prioriteit gesien en dienste word nie na buite gelewer ten koste van die "huisgenote van die geloof" nie.

\subsection{Volkskongresse}

Die groot volkskongresse wat op inisiatief van die NG Kerk gehou is, het ook die Natalse Kerk daarby betrek. Alhoewel hierdie kongresse goed bedoel en baie nodig was, het dit die volkskerkgedagte en die apartheidsfilosofie, ook in Natal, net verder versterk.

' $n$ Reeks volkskongresse is van 1916, tot so laat as 1963 gehou om aan die verskillende aspekte van die armblankevraagstuk van die tyd aandag te gee (Van der Watt 1987:288).

Die Federale Armesorgraad het handelend opgetree in die reëling van die historiese Armblankekongres in 1934 te Kimberley. Die twee belangrikste resultate van diè kongres was dat die armoedeprobleem daarna baie meer wetenskaplik benader is en dat die regering versoek is om ' $n$ staatsdepartement vir "Maatskaplike Welvaart" daar te stel (Van der Watt 1987:290). Hierdie gevolge het natuurlik ook 'n groot invloed op die Natalse Kerk gehad.

'n Opvolgkonferensie word in 1936 in Johannesburg gehou om vas te stel "in hoeverre die volk geslaag het om uitvoering te gee aan die besluite van die Armblankevraagstuk-Kongres in 1934 in Kimberley" (Notule van die Sinode van Natal 1937).

In 1936 doen die Voortsettingskomitee van die Volkskongres ' $n$ beroep op elke kerkraad in Natal om ' $n$ bydrae vir die bestudering van die Armblankevraagstuk te maak. Alhoewel die Sinodale Armesorgkommissie ' $n$ bedrag van $£ 10$ per gemeente voorstel, besluit die Sinode dat gemeentes eerder ' $n$ kollekte opneem vir die werk (Notule van die Sinode van Natal 1936). Die Sinode was klaarblyklik versigtig om die reeds sukkelende gemeentes te verbind aan ' $n$ vaste bedrag. Uit die bogenoemde aanhalings is dit duidelik dat hierdie ietwat apatiese houding nie was omdat Natal nie dieselfde sterk gevoelens vir die Afrikanersaak as ander Sinodes gehad het nie. Die besluit op ' $n$ kollekte was eerder ' $n$ finansiële besluit.

Die Volkskongres van 1 - 4 Julie 1947 in Johannesburg is deur die Federale Armesorgraad, saam met die Randse Armesorgraad, gereël en het gehandel oor die "Stadswaartse trek van die Afrikanernasie". Oor rasseverhoudinge is ' $n$ aantal besluite geneem, byvoorbeeld, dat ' $n$ beleid van rasseapartheid op alle terreine deurgevoer moes word, dat nie-blanke besetting van die stede verhoed moes word deur nywerhede in nie-blanke gebiede te 
vestig en dat aparte woongebiede vir nie-blankes daargestel moes word (Van der Watt 1987:82).

Een van die gevolge van hierdie volkskongresse was dat verskeie arbeidskolonies ter opheffing van die Afrikaner gestig is. Hierdeur is baie mense van verarming en veragtering gered. Later was die kolonies so vooruitstrewend dat dit geprivatiseer kon word en die Kerk kon onttrek (Van der Watt 1987:289). Dit is die korrekte benadering vir die Kerk se diens van barmhartigheid, om die behoefte aan te spreek en die projek so te ontwikkel dat dit later op sy eie bene kan voortgaan.

\subsection{Kultuurorganisasies}

Daar was deurgaans ook ' $n$ noue verhouding tussen die NG Kerk en die Afrikaanse kultuurorganisasies. Veral die barmhartigheidstrukture van die Kerk het baie nou saamgewerk met kultuurorganisasies wat ook vir die opheffing van die Afrikaner wou werk. In 1940 versoek die Federale Armesorgraad die Natalse Sinodale Kommissie om, soos die ander provinsies, die FAK te nader in verband met die Reddingsdaadbond (Federale Armesorgraad 1940).

Daar kom egter ' $n$ verandering in die gesindheid van die Kerk teenoor die kultuurorganisasies wanneer die Federale Armesorgraad voel die A frikaanse kultuurorganisasies "ry op die Kerk se rug" na posisies van eer en mag. Vroeër is dieselfde met die Vroueverenigings en nou ook met die Reddingsdaadbond, die FAK en die Ossewabrandwag ervaar. Dit is om die rede dat die Kerk meer seggenskap in die Reddingsdaadbond wou verkry (Federale Armesorgraad 1941).

Op die Federale Armesorgraad se vergadering in 1961 kom die behoefte aan welsynswerk onder nie-Blankes, en veral die Kleurlinge, vir die eerste keer ter sprake. Die gesindheid van die vergadering is dat dit wat vir die Afrikaners geld, ook vir ander bevolkingsgroepe gegun moet word (Federale Armesorgraad 1961).

\subsection{Beoordeling}

$\mathrm{Na}$ alles wat hierbo gesê is, sou dit tog simplisties wees om die NG Kerk van Natal ongekwalifiseerd van politiekery te beskuldig. Selfs nie binne sy barmhartigheidsbediening, waar die klem op die Afrikaner volksgenoot soos ' $n$ goue draad deur alles loop, sal hierdie beskuldiging ongekwalifiseerd kan stand hou nie.

In 1961 rig die Armesorgsekretaris, ds P Cronje, 'n versoek aan die Sinode om homself as Lid van die Provinsiale Raad verkiesbaar te stel. Een van die belangrikste redes wat hy vir die versoek aanvoer, is die groot rol wat hy as Armesorgsekretaris in die Provinsiale Raad kan speel en die positiewe gevolge wat dit vir die Kerk en by name vir die Armesorgkommissie sou inhou. Dit lyk na 'n suiwer motief vir die versoek. Tog het die Sinode dit nie goedgekeur nie omdat dit, volgens die Sinode, 'n partypolitieke 
posisie sou beteken. Die Kerk was nie bereid om in die partypolitiek betrokke te raak nie (Notule van die Sinode van Natal 1961:700).

Aan die ander kant is dit natuurlik nie verkeerd om in die eerste plek na die nood van die "huisgenote van die geloof" om te sien nie (Gal 6:10). Maar indien alle diens van barmhartigheid slegs op die eie volksgroep gerig word, en dikwels ten koste van die nood van ander, raak dit ' $n$ probleem.

\section{DIENS VAN BARMHARTIGHEID IN SAMEWERKING MET DIE STAAT}

\subsection{Inleiding}

Tussen 1652 en 1795 was daar haas geen kerklike terrein wat nie aan staatsinmenging blootgestel was nie. Die regering in die Kaap was die Here XVII uit Nederland en die plaaslike Politieke Raad (Van der Watt 1976: 66). Die Kommissaris-Politiek het selfs namens die staat kerkraadsvergaderings bygewoon (Van der Watt 1976:67). Tog was daar in die beginjare geen noemenswaardige wrywing nie.

De Mist se Kerkorde tydens die Bataafse bewind (1803 - 1806) wou kerk en staat van mekaar skei. In praktyk was die kerk egter steeds onderworpe aan die staat, alhoewel die NG Kerk sy bevoorregte posisie verloor het. "Kerklike toestande het uitgewys dat ons nie langer ' $n$ staatskerk het nie, maar wel 'n staatsdepartement" (Van der Watt 1976:70). Die Kerkorde van De Mist het geen wesenlike verskil ten opsigte van Diens van Barmhartigheid gebring nie. Die Owerheid kry egter oppertoesig oor alre kerklike administrasie en gemeentes moes jaarliks verslag lewer van barmhartigheidswerk en -uitgawes (Van der Watt 1976:57).

"Gewoond aan die praktyk dat die kerk aan die staat ondergeskik was, is hierdie verkeerde beginsel ook in die Voortrekkergemeenskap gehandhaaf: Piet Retief het die amp van kommissaris-politiek vervul (hierdie Kaapse gebruik het aan die owerheid verteenwoordiging gegee in kerklike vergaderinge)" (Van der Watt 1977:23).

In 1873 neem die Sinode kennis van die "Church Bill" wat deur die Volksraad ("Council") gepromulgeer is (Notule van die Sinode van Natal 1873). Hierdie Wet het die regspersoon en regsaanspreeklikheid van die Sinode en gemeentes van die NG Kerk erken (Notule van die Sinode van Natal 1896:23). Hiermee het die staat en kerk se paaie in Natal kerkregtelik uitmekaar gegaan, maar later weer ten opsigte van die barmhartigheidsdiens in mekaar gevloei.

\subsection{Diens van Barmhartigheid}

Op die terrein van diens van barmhartigheid was daar van die begin af die aller nouste samewerking tussen kerk en staat. Hierdie samewerking het ' $n$ 
hoogtepunt bereik in die eerste paar dekades van hierdie eeu toe die armoedeprobleem groot insette van beide staat en kerk gevra het.

$\mathrm{Na}$ die stigting van die Federale Armesorgraad in 1933 is gepoog om die ondergeskikte rol van die kerk teenoor die staat ten minste op die armsorgterrein te verander na 'n volwaardige samewerking tussen twee gelykes. Aanvanklik het die kerk selfs leiding geneem op die gebied van armsorg en by die staat aangedring op ' $n$ Subdepartement van Sosiale Welvaart onder die Departement van Arbeid. Op sy vergadering in 1935 neem die Armesorgraad kennis dat sodanige Subdepartement in die lewe geroep is en besluit die vergadering dat daar voortdurend vir goeie samewerking tussen staat en kerk gepoog sal word (Federale Armesorgraad 1935). "Dit is sonder twyfel ' $n$ feit dat die NG Kerk baie daartoe bygedra het om die staat sy roeping ten opsigte van armoede en verarming te laat nakom" (Van der Watt 1987:301). Volkskongresse is gehou en die owerheid is dikwels direk genader met die oog op wetgewing. Ongelukkig was die kerk se volle aandag, en daarom ook aanvanklik die aandag van die owerheid, uitsluitlik op die Armblanke toegespits.

Kommissies en beheerrade het met staatstrukture saamgewerk sonder om hul Skriftuurlike aard en wese prys te gee (Van der Watt 1987:302). Hierin het die kerk in Natal ook getrou gebly aan die Bybelse roeping. Samewerkingsooreenkomste is gesluit, bespreek en aangepas, en afgevaardigdes van die kerk het gereeld met die Minister onderhandel. Ds. P du Toit is selfs aangestel as die eerste Kommissaris van Volkswelsyn, en as erelid van die Armesorgraad benoem (Federale Armesorgraad 1936).

Hierdie noue samewerking tussen kerk en staat het ongelukkig veral oor subsidies gegaan en dit was heel gou die belangrikste, en dikwels die enigste punt van bespreking in die gereelde ontmoetings tussen staat en kerk. Teen die einde van die dertigerjare het die Departement van Volkswelsyn verklaar dat die NG Kerk vanweë sy verlede en prestasies geregtig is op staatsteun (Van der Watt 1987:302). Die NG Kerk het hom hiermee weer in ' $n$ bevoorregte posisie bevind, soos in die dae van die Hollandse bewind aan die Kaap toe hy die staatskerk was.

Die Kommissaris van Volkswelsyn, ds. Du Toit, dring byvoorbeeld in 1936 by die kerk daarop aan om van die $£ 800$ gebruik te maak wat die staat begroot het vir welvaartswerkers, anders kan dit dalk in die toekoms geskrap word (Federale Armesorgraad 1936).

Alhoewel hierdie aandrang van ds Du Toit goed bedoel was, was dit ' $n$ groot fout, aangesien dit as die begin van die kerk se finansiële afhanklikheid van die staat op die terrein van diens van barmhartigheid aangetoon kan word. Die Federale Armesorgraad besluit wel om ook iets by te dra vir die gesamentlike werksaamhede, maar dit was altyd minder as wat die staat bygedra het (Federale Armesorgraad 1937).

Voortaan is die kerk se finansiële afhanklikheid van die staat ' $n$ voldonge feit. In 1940 kondig die Departement van Volkswelsyn aan die een- 
kant aan dat hoofde van goedgekeurde inrigtings gesubsidieer sal word, maar maak die Federale Armesorgraad aan die ander kant beswaar omdat die Departement nuwe maatskaplike werkposte weereens nie wil subsidieer nie (Federale Armesorgraad 1941).

Die verhouding kerk-staat kan van hier af as ' $n$ interessante tweeslagtigheid beskryf word. Deur die jare was daar op verskillende terreine van die maatskaplike diensveld positiewe samewerking tussen die staat en die Kerk. Veral met die oprigting van inrigtings, versorging van inwoners, salarissubsidies, welsynswetgewing, ensovoorts was daar deurlopend baie goeie samewerking (Van der Watt 1987:302).

Aan die ander kant was daar voortdurend tekens van spanning en grensoorskrydings tussen kerk en staat. By die Armesorgraad is vrees uitgespreek dat kinderhuise te veel onder invloed van die staat kom en dat die kerk gevolglik sy seggenskap verloor. Nadat kinderhuishoofde die Sekretaris van Volkswelsyn ontmoet het, word ' $n$ verhoging in die toelae per kind per maand aangekondig, maar word die bekommernis van die Armesorgraad herhaal oor die "toenemende mate van ingryping van die Departement" (Federale Armesorgraad 1941).

' $n$ Voorbeeld van hoe die terreine vermeng en grense tussen kerk en staat oorkry is, is die onderhoud met die Minister van Volkswelsyn, minister Stals, ten einde ' $n$ kommissie van ondersoek na die gesinslewe daar te stel. Sodanige staatskommissie sou noodwendig ook uit ander persone bestaan. Die kerk het egter net in die Afrikaanse gesinne belang gestel en die Minister stel voor dat die kerk 'n eie kommissie kry. Die uitgawes van hierdie kerklike kommissie sou dan $50 \%$ deur die staat gesubsidieer word. Aan die ander kant word weer beswaar aangeteken omdat die maatskaplike strukture van die kerk minder staatsubsidies as ander welsynsorganisasies kry (Federale Armesorgraad 1949).

' $n$ Vaste patroon in die verhouding kerk-staat het in dié tyd ontwikkel. Die kerk vra verhogings in subsidies, die staat kondig subsidieverhogings aan, die kerk is dankbaar en vra verdere verhogings. Dit was veral die staatstoelae vir die administrasie van die vier Armesorgkommissies wat groot dankbaarheid by die kerk gebring het (Federale Armesorgraad 1945).

Deur die jare het die kerk dus finansieel ten volle van die staat afhanklik geword en kan weinig van die kerklike inrigtings en werksaamhede vandag sonder staatsubsidies voortgaan. Die gevolg is dat die staat enige vereiste vir die werk kan stel en dat die kerk in der waarheid nie " $n$ keuse het as om daaraan uitvoering te gee nie. Indien die kerk tans oor staatsubsidies sou moes besluit sou dit by baie van sy dienste eenvoudig ' $n$ keuse tussen staatsubsidies of die sluiting van die diens beteken.

\subsection{Natal}

Die kerk en staat het mekaar, ook in Natal, as vennote gesien en gepoog om as vennote saam te werk. Tog was dit nie altyd so eenvoudig nie. In 1932 
spreek die Sinode van Natal sy afkeur uit oor die wyse waarop die departement kinders na Greytown Kinderhuis oorplaas Hierdie handelswyse veroorsaak dat lidmate belangstelling verloor (Notule van die Sinode van Natal 1932). In Januarie van daardie jaar het die Weeshuiskomitee ' $n$ omsendskrywe van die departement ontvang oor die opname van kinders in die Weeshuis. Die twee sake wat deur hierdie omsendbrief in gedrang gekom het was die reg van die Komitee om kinders toelating te weier en die beginsel om in die eerste plek voorsiening te mak vir kinders van Natal (Notule van die Weeshuiskomitee 29.1.1932). Indien die departement hierin sy grense sou oorskrei, sou dit inderdaad veroorsaak dat lidmate belangstelling in die weeshuis en sy kinders verloor.

In 1937 versoek die Sinode van Natal, op aanbeveling van sy Armesorgkommissie en die Federale Armesorgraad, die Regering om die afdeling "Volkswelsyn" van die Departement van Arbeid te omskep in ' $n$ selfstandige staatsdepartement (Notule van die Sinode van Natal 1937). Dieselfde jaar nog gee die staat hieraan uitvoering met die stigting van die departement van Volkswelsyn.

In sy verslag aan die Sinode van 1937 maak die Armesorgkommissie van Natal onderskeid tussen die werk van die staat en die werk van die kerk. Ekonomiese opheffingswerk is gesien as die werk van die staat terwyl geestelike opheffingswerk die verantwoordelikheid van die kerk is. Daar is egter ook ' $n$ gemeenskaplike terrein waar kerk en staat moet saamwerk. Sake soos die huisgesin, die kind, opvoeding, werkloosheid, behuising, gesondheid, ensovoorts word genoem as aangeleenthede wat op hierdie gemeenskaplike terrein lê. Hiermee het die Kerk aanvaar dat hy nie alleen 'n groot geestelike roeping het nie, maar ook 'n maatskaplik-sosiale verantwoordelikheid dra (Notule van die Sinode van Natal 1937).

Die bogenoemde onderskeid tussen ekonomiese en geestelike opheffing is natuurlik kunsmatig en kon nie in die praktyk so realiseer nie. Ware barmhartigheidsdiens is juis die holistiese sorg vir iemand in nood en kan nie tot een aspek van die nood beperk word nie. Op dieselfde sinodesitting was alreeds bewyse dat sodanige onderskeid ook nie in die praktyk kan werk nie.

Die staat was gretig om, met sy geldkrag, sy ekonomiese verantwoordelikheid na te kom. Dit het egter tot gevolg gehad dat die arme al meer die hulp van die staat raakgesien het en al minder die liefde en simpatie van die kerk. Op sy beurt het dit weer geleidelik tot vervreemding tussen die kerk en die minder bevoorregte gelei. Aan die ander kant was dit baie belangrik dat hierdie mense nie vir die kerk verlore sou gaan nie. Daarom besluit die Sinode om na alle kerkrade aan te beveel om 'n plaaslike armesorgkommissie te kies wat " $n$ "wakkere oog" sou hou oor die armes in die gemeente. Hierdie plaaslike armesorgkommissies moes ook die armes behulpsaam wees in die aansoeke vir staatspensioene (Notule van die Sinode van Natal 1937). 
Dit was voorts vir die kerk belangrik om inspraak te kry in "komitees vir Ouderdomspensioene, Jeugrade, Blindemenspensioen, Pensioene vir Liggaamlik-ongeskiktes, plaaslike weldadigheidsorganisasies, Kindersorg verenigings, ensovoorts", om die koers aan te wys en die kerk se rol in die maatskaplike dienslewering te bevestig (Notule van die Sinode van Natal 1937).

Soos reeds in die vorige paragraaf aangedui was daar van tyd tot tyd agterdog by die kerk oor staatsinmenging op die kerklike terrein. Hierdie agterdog tree veral op die voorgrond met ' $n$ nuwe regulasie wat deur die regering uitgevaardig word ten opsigte van weeshuise. Die Konstitusie van die Greytownse Weeshuis moes volgens dié nuwe regulasie soos volg gewysig word: "Die Minister kan, as 'n voorwaarde vir die verlenging of hernuwing van ' $n$ sertifikaat, vroeër verleen aan ' $n$ inrigting of tehuis, vereis dat bevoegdheid aan hom verleen word, desnoods deur wysiging van die Konstitusie daarvan, om " $n$ vasgestelde aantal of gedeelte van lede van die Bestuur aan te stel" (Notule van die Sinode van Natal 1942).

Hierdie nuwe bepaling is " $n$ totale ingrype in die outonomiteit van die Beheerraad en die kerk. Die Sinode keur die wysiging aan die Konstitusie so goed, nadat verduidelik is dat die Minister sodanige magte aan hom verleen slegs by hoë uitsondering sal gebruik (Notule van die Sinode van Natal 1942). Hiermee het die staat weer sy terrein oortskrei en is daar, op die terrein van die barmhartigheidsdiens, teruggekeer na ' $n$ ondergeskikte rol van die kerk aan die staat. Omdat dit nie op die breë kerkregtelike terrein was nie, maar slegs op die terrein van die barmhartigheidsdiens, is dit deur die kerk aanvaar.

Aan die ander kant maak Greytown Kinderhuis in sy verslag aan die Sinode van 1942 melding van die feit dat die staat meer as $50 \%$ van die inkomste van die Kinderhuis bydra (Notule van die Sinode van Natal 1942). Reeds hier raak dit duidelik dat die Kinderhuis net nie meer sonder staatsubsidies sou kon voortgaan nie. Hiermee is die finansiële afhanklikheid van die kerk se inrigtingsorg van staatsubsidies ook in Natal finaal bevestig.

Teen 1954 is die Sinodale Armesorgkommissie van Natal ook volgens Wet no. 40 van 1947 geregistreer as welsynsliggaam en kon daar voortaan amptelik aanspraak op subsidies gemaak word (Handelinge van die Sinode van Natal 1954:156).

Die Sinode van 1954 neem met groot dank kennis van die beleid wat deur die Minister van Volkswelsyn neergelê is, naamlik dat ' $n$ sorgbehoewende persoon deur Departementele kantore na sy geloofs- en volksgenote vir behandeling verwys sal word (Handelinge van die Sinode van Natal 1954:156).

Die verhouding en samewerking tussen kerk en staat in Natal was oor die algemeen baie goed en versoeke van kerklike kant is gewoonlik deur die departement positief oorweeg. In 1957 is byvoorbeeld twee kerk- 
like amptenare, op aandrang van die Sinodale Armesorgkommissie, op die Natalse Welsynsraad aangewys (Handelinge van die Sinode van Natal 1957:150).

In 1965 het die kerk tot soveel as $29 \%$ van die uitgawes van die CM Rade (die maatskaplike veldwerkorganisasies van die kerk) bygedra. Dit was egter steeds meer as wat die staat daardie jaar bygedra het (Agenda van die Sinode van Natal 1965: SKDB verslag). Teen die tyd was die kerk se inrigtings reeds volledig afhanklik van staatsubsidies en sou dit net ' $n$ kwessie van tyd wees totdat die CM Rade ook finansieel van die staat afhanklik sou wees.

Teen 1979 neem die Sinode kennis dat die staat nou ook administratiewe hulpdienste vir die ondersteuning van die maatskaplike werker subsidieer. In praktyk het dit daarop neergekom dat die staat $75 \%$ van die maatskaplike werker se salaris, en $75 \%$ van ' $n$ administratiewe assistent se salaris vir elke goedgekeurde maatskaplike werkerspos subsidieer (Agenda van die Sinode van Natal 1979:173). Daarmee was die afhanklikheid van die CM Rade nou ook ' $n$ voldonge feit.

Teenoor ' $n$ finansiële afhanklikheid het daar andersins tog ' $n$ beter samewerking tussen staat en kerk as gelyke vennote begin ontwikkel. In die tagtigerjare lewer die SKDB en AKDB, saam met ander welsynsorganisasies, gereeld kommentaar op voorgestelde nuwe wetgewing. Die kerk het veral groot insette gelewer op die Wet op Kindersorg van 1983 en die Nasionale Welsynswet van 1978 (Agenda van die Sinode van Natal 1987: 164).

In 1991 neem die Sinode kennis van ' $n$ nuwe subsidiebeleid van die regering. Subsidies sou voortaan ten nouste saamhang met die indiening van duidelike en gemotiveerde welsynsprogramme waarin ' $n$ instansie se doelwitbeplanning uiteengesit word (Agenda van die Sinode van Natal 1991:55). Alhoewel sommige hierdie verwikkeling gesien het as 'n inmenging van regeringskant in die kerklike werk, was dit tog in twee opsigte ' $n$ goeie vereiste. Aan die een kant het dit die betrokke staatsdepartement in die posisie gestel om deeglik kennis te neem van wat met sy subsidies gebeur. Dit kan tog nie as ' $n$ inmenging van staatskant gesien word as die regering seker wil maak wat met sy fondse gebeur nie. Aan die ander kant het hierdie vereiste alle gesubsidieerde dienste verplig om jaarliks behoorlik te beplan. Hierdie goeie doelwitbeplanning van die Kerk se welsynsorganisasie kan beslis ook deur ander strukture en dienste van die Kerk ten goede gebruik word.

Dit sou ' $n$ eensydige voorstelling wees indien beweer word dat die kerk hierdie stand van staatsafhanklikheid goedkeurend aanvaar het en niks daaraan wou doen nie. Die kerk het deurlopend gepoog om in die barmhartigheidsbediening aan te sluit by die riglyne en beplanning van die welsynsowerheid sonder om die Christelike beginsels prys te gee. Veral sedert die demokratiese verkiesings in 1994 het daar groot veranderings in staatsbe- 
leid ingetree, wat die kerk noodwendig moes verreken. Die Sinode van 1995 neem soos volg hiervan kennis: "In die nuwe en snel veranderende samelewing, kom die barmhartigheidsdienste van die Kerk al meer in die kollig. Sake soos die groter openheid na ander gemeenskappe, staatsubsidies, die Heropbou- en Ontwikkelingsprogram van die regering, ensovoorts, vra die deurlopende aandag en beplanning van die SKDB. Die groot uitdaging van die dag is om met minder fondse meer te doen" (Agenda van die Sinode van Natal 1995:72).

Alhoewel daar dus in die lig van die bevriesing van subsidies deur die owerheid geen uitbreiding in poste of diensvertakkings van die SKDB was nie, is deeglik besef dat die uitbreiding van dienste, veral in ' $n$ tyd van armoede, nie deur staatsubsidies beperk mag word nie. Hiermee is die noodsaaklikheid en die wil om die afhanklikheid van staatsubsidies te deurbreek uitgespel.

Met die koms van die nuwe staatkundige bedeling het daar ook groot veranderings ten opsigte van die subsidiëring van welsynsorganisasies gekom. Alle inrigtings en CM Rade doen voortaan deurlopende finansiële beplanning om sover moontlik gereed te wees vir moontlike subsidieverlagings (Agenda van die Sinode van Natal 1995:75).

Die vooruitsig bestaan dat die kerk ook hierdie krisis in sy geskiedenis sal oorkom en sal kan voortgaan om barmhartigheidsdienste te lewer aan hulle in nood. In diè tyd kry die bede van Psalm 138:8 ook weer nuwe betekenis, "moet tog nie die werk van u hande laat vaar nie."

\section{INTERPRETASIE EN BEOORDELING}

\subsection{Hipotese 1}

In die verhouding kerk - staat was daar in der waarheid sedert die Christendom die staatsgodsdiens geraak het in die tyd van Konstantyn voortdurende spanning. Soms het die staat die grootste gesag in hom gedra en dan die kerk oorheers. Ander tye het die kerk weer die groter gesag gehad en dan aan die staat voorgeskryf. Met die noue vennootskapsverhouding tussen kerk en staat in Suid-Afrika was dit van die begin af ook hier nie anders gewees nie.

Die spanning in hierdie vennootskapsverhouding het veral op die terrein van die diens van barmhartigheid sterk na vore getree. Ook hier het die kerk en staat van tyd tot tyd hul terreine oortree en onhaalbare voorskrifte en vereistes aan mekaar gestel. Finansieel het die kerk wel mettertyd ten opsigte van sy diens van barmhartigheid te afhanklik van die staat geraak. Die gevolg is dat die staat later enige vereiste kon stel met die wete dat die kerk dit nie sou kon weier nie. In die dae toe die kerk en staat dieselfde oor sake gedink het, en daar ' $n$ baie noue vennootskap tussen die twee was, was hierdie afhanklikheid natuurlik nie ' $n$ groot probleem nie. 
Die nuwe demokratiese regering na 1994 het egter op verskeie terreine ander sieninge as die kerk, wat nou weer spanning in die verhouding bring.

Die samewerking met die staat het dus deur die jare in ' $n$ ongesonde afhanklikheid ontwikkel. Die gevolg is dat daar tans 'n groot mate van onsekerheid is oor die toekoms van die kerk se maatskaplike dienste. Van gelyke vennote in hierdie samewerkingsverhouding is daar nie meer sprake nie. Hierdie deurlopende lyn in die geskiedenis moet as negatief beoordeel word en indien die kerklike barmhartigheidsdiens hiervan kan loskom, sal hy die volgende millennium met vryheid kan ingaan.

Twee dinge moet in hierdie verhouding gebeur. Aan die een kant moet die kerk homself al meer onafhanklik maak van die staatsubsidies, wat ' $n$ groot mate van bevryding sal meebring. Aan die ander kant moet die vennootskapsverhouding tussen kerk en staat uitgebou en op 'n vaste voet geplaas word. Die werklikheid waarby nie een van die partye verby kan kom nie is dat beide ' $n$ verantwoordelikheid teenoor dieselfde mense het. Die staat het ' $n$ maatskaplike verantwoordelikheid teenoor sy burgers wat nie nagelaat mag word nie en die kerk het ' $n$ barmhartigheidsopdrag teenoor gelowiges en ongelowiges, dieselfde staatsburgers, wat ook nie nagelaat kan word nie. Daarom sal kerk en staat deurlopend aan die genoemde vennootskapsverhouding moet werk.

\subsection{Hipotese 2}

Die kerk se besondere barmhartigheidsbetrokkenheid by die Afrikanervolk het inderdaad sy spontane betrokkenheid by ander volke en kultuurgroepe negeer. Soos aangetoon is hierdie betrokkenheid van die kerk by sy eie lidmate natuurlik nie as sodanig verkeerd nie. Wat wel in ' $n$ verkeerde rigting ontwikkel het is toe die apartheidsideologie ook op hierdie terrein van die kerklike werk sy invloed laat gelḍ het. Die kerk het so op die nood van sy eie (Afrikaner) lidmate gekonsentreer, dat daar nie in die barmhartigheidsbediening plek en tyd oor was vir die nood en behoeftes van ander bevolkingsgroepe nie.

Die gevolgtrekking wat aan die begin gemaak is, is in die studie bevestig. Hierdie vroeëre uitsluiting van ander volke uit die kerk se barmhartigheidsbediening het die kerk se bona fides by ander bevolkingsgroepe in gedrang gebring. Daarom sal die NG Kerk van Natal weer sy staanplek in die samelewing moet verdien. Dit sal sodanig gedoen moet word dat alle mense, gelowiges en ongelowiges, die goeie bedoelings wat deur die geskiedenis die werk van die kerk gekenmerk het, sal raaksien en aanvaar.

Die gevaar bestaan natuurlik dat die barmhartigheidsbediening aan ander nou weer ten koste van die versorging van die eie lidmate en "huisgenote van die geloof" kan geskied. Dan sal die kerk weer in " $n$ eensydige oorbeklemtoning van die ander kant verval.

Die NG Kerk van Natal se barmhartigheidsbediening was dus inderdaad eksklusief en afhanklik. Sedert die eerste demokratiese verkiesing van 
1994 het die kerk egter reeds self aanpassings begin maak en bly die uitdaging dat die kerk se barmhartigheidsdiens in die nuwe millenium inklusief en onafhanklik sal raak. Hiermee sal die NG Kerk weer sy staanplek in die nuwe SA verdien en sy roeping vervul.

\section{Literatuurverwysings}

Die bronnelys word in primêre en sekondêre bronne verdeel. Die skrywer was bevoorreg om hoofsaaklik van primêre bronne gebruik te kon maak.

\section{Primêre Bronne}

Algemene Sinode 1962 - 1994. Agendas en Verslae. Ongepubliseer. Algemene Sinode 1962 - 1994. Notules en Verslae. Ongepubliseer.

Algemene Sinode 1986. Kerk en Samelewing: 'n Getuienis van die Ned Geref Kerk. Bloemfontein: NG Sendingpers.

Departement van Welsyn 1997. White Paper for Social Welfare. Pretoria: Staatdrukker.

Die Kerkbode. 15.2.1939. Kaapstad.

Federale Armesorgraad 1933 - 1951. Notules (Volume I). Ongepubliseer.

Federale Armesorgraad 1952 - 1962. Notules (Volume II). Ongepubliseer.

Ned Geref Kerk 1994. Die Kerkorde. Wellington: Hugenote-Uitgewers.

Ned Geref Kerk Greytown 1859-1910. Kerkraadsnotules. Ongepubliseer.

Ned Geref Kerk Greytown 1959. Eeufeesbrosjure. Ongepubliseer.

Ned Geref.Kerk van Natal 1996. Die Kerkorde. Ongepubliseer.

Republic of South-Africa, 1996. Constitution of the Republic of South Africa No. 108 of 1996. Cape Town, Government Gazette.

Republiek van Suid-Afrika, 1983. Wet op Kindersorg No. 74 van 1983. Kaapstad: Staatskoerant.

Sinodale Armesorgkommissie van Natal 1930 - 1960. Notules. Ongepubliseer. -

Sinodale Kommissie vir Administrasie in Natal 1970 - 1998. Notules. Ongepubliseer.

Sinodale Kommissie vir Diens van Barmhartigheid in Natal 1961 - 1997. Notules.

Ongepubliseer.

Sinodale Kommissie vir Diens van Barmhartigheid in Natal 1962 - 1997. Jaarverslae. Ongepubliseer.

Sinodale Sendingkommissie van Natal 1964-1976. Notules. Ongepubliseer.

Sinode van Natal 1865 - 1995. Agendas en Verslae. Ongepubliseer.

Sinode van Natal 1865 - 1995. Notules en Verslae. Ongepubliseer.

Van Niekerk, P \& Orkin, M 1991. The NGKA in its Community - Contextual Analysis for Social Action on Poverty and Dependence. Johannesburg: NGKA.

Vergaderings van Hoof Maatskaplike Werkers 1992 - 1998. Notules. Ongepubliseer.

Vergaderings van Kinderhuishoofde in Natal 1992-1998. Notules. Ongepubliseer.

Vrouediens van Natal.Gemeenteverslae. Argief V3/24: Ongepubliseer.

\section{Sekondêre Bronne}

Bosch, D J 1991. Transforming Missions - Paradigm Shifts in Theology of Mission. New York: Orbis Books.

Botha, J \& Naudè, P 1998. Op pad met Belhar. Pretoria: JL van Schaik Uitgewers.

Crafford, D 1982. Aan God die Dank. Deel 1. Pretoria: NG Kerkboekhandel.

Crafford, D 1978. Die sosiale betrokkenheid van die Kerk in die Sending, Ekumene en Praktyk. Goodwood: NG Kerkboekhandel. 
De Gruchy, J W 1979. The Church struggle in South Africa. Cape Town: Wm. B. Eerdmans Publishing Co.

De Klerk, J J 1976. Weldadigheid en Mededeelsaamheid. Pretoria: NG Kerkboekhandel.

De Klerk, J J (red) 1990. Die Diens van Barmhartigheid en die Nederduitse Gereformeerde Kerk. Kaapstad: NG Kerk-Uitgewers.

Gerdener, G B A 1934. Ons Kerk in die Transgariep: Geskiedenis van die Ned Geref Kerke in Natal, Vrystaat en Transvaal. Kaapstad: Nasionale Pers.

Haasbroek, E \& Marais, S. Geskiedkundige uittreksels: Natalse Vrouesendingbond 1939 - 1976. Ongepubliseer.

Heyns, J A 1977. Die Kerk. Pretoria: NG Kerkboekhandel.

Hofmeyr, J W \& Pillay, G J (red) 1994. A History of Christianity in South Africa (Volume 1). Pretoria: HAUM Tertiary.

Kartes, D J 1969. De Gemeente en haar Diakonaat. 's-Gravenhage: Boekencentrum.

Kinghorn, J (red) 1986. Die NG Kerk en Apartheid. Braamfontein: Macmillan SuidAfrika. Kaapstad: Hugenote-Uitgewers.

Lindeque, R C 1982. Die Maatskaplike werk van die Nederduitse Gereformeerde Kerk. D.Phil. proefskrif, Universiteit van Pretoria.

Mbiti, J S 1969. African Religions and Philosophy. London: Heinemann.

Möller, D F 1995. Kerk en Ontwikkeling - Met verwysing na die missionère roeping van die kerk. DD-proefskrif, Universiteit van Pretoria.

Nieuwoudt, M M 1986. Maatskaplike betrokkenheid van die Kerk in Suid-Afrika: Prinsipiële Riglyne. Studia Historiae Ecclesiasticae. 1-15.

Oosthuizen, A 1995. Gemeentediakonaat as plaasvervanger vir Staatsondersteunde Sinodale Barmhartigheidsdiens in die Ned Geref Kerk - 'n Langverwagte "noodwendige" regstelling. D.Th. proefskrif, Universiteit van die OVS.

Pretorius, L A 1988. Heil of Gemeenskapsontwikkeling? - 'n Ondersoek na kerklikdiakonale betrokkenheid in die Suider-Afrikaanse konteks. D.Th. proefskrif, Universiteit van Suid-A frika.

Van der Watt, P B 1976. Die Nederduitse Gereformeerde Kerk 1652 - 1824 (deel een). Pretoria: NGK Boekhandel.

Van der Watt, P B 1977. Die Nederduitse Gereformeerde Kerk 1834 - 1866 (deel twee). Pretoria: NGK Boekhandel.

Van der Watt, P B 1980. Die Nederduitse Gereformeerde Kerk 1824 - 1905 (deel drie). Pretoria: NGK Boekhandel.

Van der Watt, P B 1987. Die Nederduitse Gereformeerde Kerk 1905 - 1975 (deel vier). Pretoria: NGK Boekhandel.

Van't Spijker, W 1981. Triptiek van de Geschiedenis: de verhouding tussen wereldheils-en kerkgeschiedenis. Goes: Oosterbaan \& Le Cointre BV.

Wilson, F \& Ramphele, M 1989. Uprooting Poverty: The South African challenge. Cape Town: David Philip. 